\title{
Effect of Invasive Aquatic Plants (Azolla a., Myriophyllum a. and Cyperus a.) Biochar Amendment on Maize Growth: An Assessment
}

Sidbe Wendin Nestor Ouedraogo (corresponding author)

Permanent Secretariat of the National Council for the Environment and Sustainable

Development, Burkina Faso. 01 BP 6486 Ouagadougou 01

E-mail: ouedranestor@yahoo.fr / Phone: +226 70229979

\author{
Koffi Komoe \\ Université Félix Houphouët Boigny, Côte d'Ivoire. 22 BP 582 Abidjan 22 \\ E-mail: komoek@yahoo.fr / Phone: +22508 007488
}

\begin{abstract}
Désiré Jean Pascal Lompo
University of Dédougou, BP 176, Dédougou, Burkina Faso

E-mail: lompodesire@yahoo.fr / Phone: +226 70278758
\end{abstract}

Sié Sylvestre Da

West African Science Service Center on Climate Change and Adapted Land Use (WASCAL), Burkina Faso, E-mail: da_siesylvestre@yahoo.fr / Phone: +226 70144439

Osemwegie Isimemen

University of Bonn, Genscherallee 3,53113 Bonn Germany

E-mail: iosemweg@uni-bonn.de / Phone: +49 $228731721 \quad$ Fax: +49 228731889

Dominique Masse

IRD, Eco \& Sols, University of Montpellier, CIRAD, INRAE, Institut Agro, Montpellier, France; University of Nangui Abrogoua, LMI EDD BIODIV, Abidjan, Ivory Coast

E-mail: dominique.masse@ird.fr / Phone: +225 22485000 
Received: March 31, 2021

doi:10.5296/jas.v9i3.18476
Accepted: May 5, 2021 Published: August 29, 2021

URL: https://doi.org/10.5296/jas.v9i3.18476

\begin{abstract}
The management of invasive aquatic plants (IAPs), which is primarily accomplished through manual grubbing, incurs significant costs for populations, especially since the operations must be renewed on a regular basis. Converting IAPs into biochar for use as soil amendment will help offset the costs of this mechanical control strategy, while also improving carbon sequestration, soil fertility and crop yields. The objective of this study is to examine the effects of using IAPs biochar amendment on the quality of acidic soils and subsequently maize growth. Ten treatment groups including nine treatments and one control were established with four replicates each on freshly sown maize soils. Treatments options include applying IAP biochar (group 1), different combinations of IAP biochar and poultry manure (group 2), and mineral fertilizer (group 3). After 37 days, the average height of maize plants in the control group is $68.83 \pm 7.91 \mathrm{~cm}$, compared to $69.82 \pm 7.34 \mathrm{~cm}$ (group1), $64.44 \pm$ $7.82 \mathrm{~cm}$ (group 2) and $69.08 \pm 9.51 \mathrm{~cm}$ (group 3). Multivariate analyses suggest that the IAPs biochar have significantly higher potential to improve plant growth parameters than either poultry manure or synthetic fertilizer. Based on the foregoing, the use of IAPs biochar amendment should be promoted among smallholder farmers because it is environmentally friendly, easy to produce, has a lower operational cost than other fertilizers, and has been shown to improve the acidic and impoverished dryland soils prevalent in Burkina Faso.
\end{abstract}

Keywords: invasive aquatic plants, biochar, fertilizer, growth parameters, maize plant

\title{
1. Introduction
}

Invasive alien species are one of the five top drivers that pose serious threats to biodiversity, ecosystem services, ecosystem health and livelihood security (Intergovernmental Platform on Biodiversity and Ecosystem Services, IPBES, 2018), These non-native taxa proliferate, disperse and persist in environments that are not originally their own, to the detriment of native species (Mack et al., 2000). In freshwater systems, biological invasion leads to altered hydrology, disruption of aquatic food web structure and changes in the biotic composition of invaded ecosystems (Strayer, 2010, Hussner et al., 2017). In Burkina Faso, several invasive aquatic plants in particular, Eichhornia crassipes (Mart.) Solms, Azolla africana (Desv.), Myriophyllum aquaticum (Vell.) Verdc., Cyperus articulatus L. (Cyperaceae) are threatening wetlands of the country (PNGIRE, 2016). These invasive aquatic plants degrade water quality and reduce its groundwater volume by raising evaporation rates by between 3 and $7 \%$ as compared to pristine water bodies (MAAH, 2016). They limit the accessibility and availability of water for human, livestock, and wildlife use and provide habitats for vectors of waterborne diseases (malaria, bilharzia, cholera, and onchocerciasis).

Local populations in Burkina Faso are developing adaptive management strategies to cope 
with and restrict the spread of invasive aquatic plants. Unfortunately, the methods that are often used are costly and have not been particularly effective. Past studies (Almoustapha and Millogo-Rasolodimby, 2006; Egnankou, 2016) have shown that converting aquatic invasive plants into compost has the potential to reduce their spread, while providing alternate fertilizers for local farmers.

The production and application of biochar material to agricultural fields, is a new technology increasingly promoted as crop residues and organic waste management, soil fertility improvement and climate change mitigation (Woolf et al., 2010; (Lompo et al, 2021a\&b). Biochar is a substance with a high stable carbon content that can be obtained by the pyrolysis (that is, relatively low temperature in the absence of oxygen) of any form of biomass, including crop, tree residues and manure (Lehmann and Joseph, 2009, Verheijen et al., 2010). Biochar has the ability to increase soil quality and crop production while sequestering carbon (Lee et al., 2015). In general, the use of biochar as soil amendment increases plant growth and crop yields by up to 200\% in tropical areas (Yao et al., 2012; Mukherjee and Lal, 2013; Adekiya et al., 2020; Lompo et al, 2021b). Biochar is a promising material, which is generating a lot of interest around the world.

Hence, this study was conducted in order to assess the potential of biochar produced from combined IAPs (Azolla a., Myriophyllum a., and Cyperus a.) on soil fertility and morphological parameters of maize plants. This is with a view to contribute to improving quality of acidic soils in Burkina Faso, and by so doing, agricultural yields and the livelihoods of smallholder farmers.

We hypothesised that biochar obtained from invasive aquatic plants could enhance agricultural productivity (maize plant growth) and aid in soil fertility management.

\section{Materials and Methods}

\subsection{The Study Area}

The study was carried out in 2020. The experimental farm plots are located in Kadomba $\left(11^{\circ} 32^{\prime} 28^{\prime \prime} \mathrm{N}\right.$ and $\left.3^{\circ} 58^{\prime} 52^{\prime \prime} \mathrm{W}\right)$, a rural community of Satiri department of Houet province in the Hauts-Bassin region. It is located $9 \mathrm{~km}$ northeast of Bala, and $50 \mathrm{~km}$ from Bobo Dioulasso the second largest city of Burkina Faso. Kadomba is characterised by a south Sudanian climate with an average annual rainfall of $1100 \mathrm{~mm}$ over a period of 4 to 5 months. The wet season lasts from May to October with $62.5 \%$ relative humidity and the dry season from November to April with relative humidity between 20.5 and $44.2 \%$. December is usually the driest month with an average rainfall of $6.2 \mathrm{~mm}$. Average temperatures are high: annual maximum temperature of $32.2^{\circ} \mathrm{C}$ is recorded in March and minimum of $25.4^{\circ} \mathrm{C}$ in December (Ouedraogo, 1994; Taita, 1998).

The soils of Kadomba are hydromorphic with pseudogley materials of various textures (ORSTOM, 1968). They appear in the form of strips and vast plains along the main drainage axes (Mouhoun and Sourou in particular).

\subsection{Plant Material}


The plant material used in this study was Zea mays L., Barka variety. This variety has a short cycle of 70 to 85 days between sowing and maturity. It has a potential yield of $5.5 \mathrm{t} / \mathrm{ha}$. The seeds are white in colour and have a horny texture. It is pests and drought tolerant and can be cultivated either as rainfed or irrigated.

\subsection{The Tested Soil Fertilizers}

The amendments used in this study were: 1) biochar produced from the pyrolysis of three invasive aquatic plants- free floating Azolla $a$. (mosquito fern), Myriophyllum $a$. (parrot's feather with submergent and emergent feathery leaves, and Cyperus $a$. (jointed flatsedge); 2) poultry litters collected from a poultry farm, and 3) mineral fertilizers.

\subsubsection{Harvesting of IAPs and Production of Biochar}

The IAPs were harvested from a N/NW-S/SE elongated lake of about a length of $2.6 \mathrm{~km}$ and breadth of $700 \mathrm{~m}$. Its surface area varies from 120 to 660 ha depending on the flooding of the Mouhoun River with which it is hydrologically connected. Its average depth is $2 \mathrm{~m}$ during low water period, and $0.5 \mathrm{~m}$ is silted. This lake is located within the The Bala (Mare aux hippopotames) Biosphere Reserve, also located in the province of Houet (Haut-Bassin region), about $50 \mathrm{~km}$ northeast of Bobo Dioulasso, straddling the Departments of Satiri and Padéma. It is surrounded by ten villages to which are attached several large farming hamlets with an estimated total population of 40,000 inhabitants. It is located in the west of Burkina Faso, between latitudes $11^{\circ} 30^{\prime}$ and $11^{\circ} 45^{\prime} \mathrm{N}$ latitude and longitudes $4^{\circ} 05^{\prime}$ and $4^{\circ} 12^{\prime} \mathrm{W}$ longitude. The Mare aux Hippopotames Biosphere Reserve (MHBR) has a surface area of 19,200 ha (Belem 2008). This lake is well-known for its hippopotamuses (Hippopotamus amphibius), which live permanently in the lake, and give rise to the reserve's name, "Réserve de biosphère de la Mare aux Hippopotames". The main activities carried out by the populations around the Bala Biosphere Reserve are agriculture, animal husbandry, fishing, and hunting. However, IAPs invasions have led to a decrease in fishery productivity. For example, fish production in Bala is on a downward trend from $600 \mathrm{~kg}$ in 1966 to 150 or $200 \mathrm{~kg}$ between 2000 and 2006 (Belem, 2008) and fish biodiversity has decreased from 42 species in 1956 to 34 species in 1994. In 2006 only 17 species were commonly encountered.

Biochar was produced by a slow carbonization (roasting) of the dried invasive weeds in the presence of little oxygen using a cone kiln oven at a temperature between 200 and $290^{\circ} \mathrm{C}$, at an average of 22 minutes for Cyperus a., 50 minutes for Myriophyllum a. and 80 minutes for Azolla a.

\subsubsection{Biochar and Manure Analysis}

Biochar samples were air dried in the shade, crushed and sieved at $2 \mathrm{~mm}$ and $0.5 \mathrm{~mm}$ mesh size for chemical analysis. The pHwater was carried out by the electro-metric method with a soil/water ratio of 1:2.5. To do this, $20 \mathrm{~g}$ of soil was taken and placed in a flask, then $50 \mathrm{ml}$ of 
distilled water was added and the mixture obtained was stirred for one hour in accordance with the FSA standard. After stirring, the $\mathrm{pH}$ of the water was read directly from the HANNA $\mathrm{pH}$ meter with glass electrode. The determination of the total carbon content was carried out by the Walkley and Black (1934) method. The organic matter content was then determined from the organic carbon content using the multiplication coefficient of 1.724. The total nitrogen determination initially consisted of mineralizing the biochar samples with a mixture of sulfuric acid-selenium-salicylic acid by gradually heating it to a temperature of $100^{\circ} \mathrm{C}$ to $340^{\circ} \mathrm{C}$. Then the total nitrogen was determined using a auto-analyzer (SKALAR). About total phosphorus, the mineralization wasidentical to that of total nitrogen. The dosage was done by automatic colorimetry with SKALAR. Ammonium molybdate and potassium antimony tartrate reacted in an acid medium with ascorbic acid to form a blue complex in the presence of phosphorus $(\mathrm{P})$ whose absorbance is measured at $880 \mathrm{~nm}$. The intensity of the coloration was proportional to the amount of $\mathrm{P}$ in the medium. For the total potassium, the mineralization method was identical to that described above for nitrogen. Potassium was determined by a Jencons flame emission spectrophotometer, following the method proposed by Walinga et al. (1989).

\subsection{Experimental Design}

The agricultural field trial was set up in a complete randomized block design (Fisher blocks). Each block consisted of ten treatments with four (4) replicates. The elementary plots were 4 $\mathrm{m}$ long and $3 \mathrm{~m}$ wide. Within a block, the elementary plots were spaced $1 \mathrm{~m}$ apart. The distance between 2 blocks was $1.5 \mathrm{~m}$. Treatments included: T0: without biochar, poultry manure or mineral fertilizer (control treatment), T1: $5 \mathrm{t} / \mathrm{ha}$ of biochar obtained from Azolla $a$, (Group 1), T2: 5 t/ha of biochar obtained from Myriophyllum a. (Group 1), T3: 5 t/ha of biochar obtained from Cyperus a. (Group 1), T4: 1.7 t/ha of biochar obtained from Azolla a.+ $1.7 \mathrm{t} / \mathrm{ha}$ of biochar obtained from Myriophyllum a.+ $1.7 \mathrm{t} / \mathrm{ha}$ of biochar obtained from Cyperus a. (Group 1), T5: 2.5 t/ha of biochar obtained from Azolla $a .+2.5$ t/ha of poultry manure (Group 2), T6: 2.5 t/ha of biochar obtained from Myriophyllum a. $+2.5 \mathrm{t} /$ ha of poultry manure (Group 2), T7: 2.5 t/ha of biochar obtained from Cyperus a.+ 2.5 t/ha of poultry manure (Group 2), T8: $150 \mathrm{~kg} / \mathrm{ha}$ of NPK 14-23-14 (Group 3), T9: 0.83 t/ha of biochar obtained from Azolla a.+ 0.83 t/ha of biochar obtained from Myriophyllum a.+ $0.83 \mathrm{t} / \mathrm{ha}$ of biochar obtained from Cyperus a. +2.5 t/ha of poultry droppings (Group 2).

The recommended rate in the field is $5 \mathrm{t} / \mathrm{ha}$ for a period of three years, renewable. For treatments T1, T2, T3 and T4 plots, $6 \mathrm{~kg}$ of biochar were applied corresponding to the recommended rate of $5 \mathrm{t} / \mathrm{ha}$. This quantity was reduced either by half $(3 \mathrm{~kg})$, or by $1 / 3$ or $1 / 6$ $(1 \mathrm{~kg})$ for the other biochar treatments. Treatments were randomly assigned to the plots.

\subsection{Crop Cultivation and Maintenance}

The experimental site was ploughed with a tractor prior to the delimitation of plots. The amendments were combined with the top $10 \mathrm{~cm}$ of soil by ploughing. Sowing was carried out on 18 January 2020. On all plots, three seeds of maize were sown per hole at a row spacing of 
$40 \mathrm{~cm}$ and line spacing of $80 \mathrm{~cm}$.

Each elementary plot had 6 rows of seed with 8 pots per row. The four central rows formed the useful area where the measurements were made and the other two rows at the ends were used as border lines, with one row per side. At 15 days, following emergence, the number of young corn plant was reduced to two in each plot. Subsequently, four plants were randomly selected and identified in each elementary plot to measure the growth parameters. These plants were then selected from the four rows of the useful plot, including one plant per row.

\subsection{Measurement of Plant Growth Parameters}

Weekly measurements of average plant height were taken with a graduated ruler. These measurements were taken from the collar of the plant to the last emerging leaf. Measurements began the third week after sowing and continued until the $37^{\text {th }}$ day after sowing (DAS). The diameters of the collars were also measured beginning the third week after sowing and continuing every week. The number of leaves per plant were counted from the third weeks onwards and continued every two weeks until the $40^{\text {th }}$ DAS. Dried leaves were included in the count.

\subsection{Data Processing}

The data from the experimental plots were analysed by analysis of variance (ANOVA) and compared using the Tukey-Dunnett Test (Fisher's Least Significant Difference) when significant $(\mathrm{P}<0.05)$. Correlation coefficients were determined by the simple regression method. This was carried out with the XLStat version 2016 software.

Principal Component Analysis (PCA) was performed on the treatments. This allowed us to quickly know which of these treatments is the most efficient and effective (the best treatment among the 9 treatments). This was followed by the Hierarchical Ascending Classification, which grouped the treatments into classes.

\section{Results}

\subsection{Chemical Properties of Biochars and the Poultry Manure}

Biochars have alkaline $\mathrm{pH}$ values ranging from 8.92 to 9.89 and high than the $\mathrm{pH}$ value of poultry manure which is almost neutral. The biochars have higher concentrations of C, O.M, and $\mathrm{K}$ compared to poultry manure. Poultry manure, on the other hand, has a high level of $\mathrm{P}$ compared to Azolla a.and Cyperus a.biochar and high N compared to Cyperus a.biochar. Concerning the $\mathrm{C} / \mathrm{N}$ biochars have small values as compared to the poultry manure except for the Cyperus a.derived biochar (Table 1). 
Table1. Chemical composition of biochar and poultry litters

Biochar from Biochar from Myriophyllum a. Biochar from

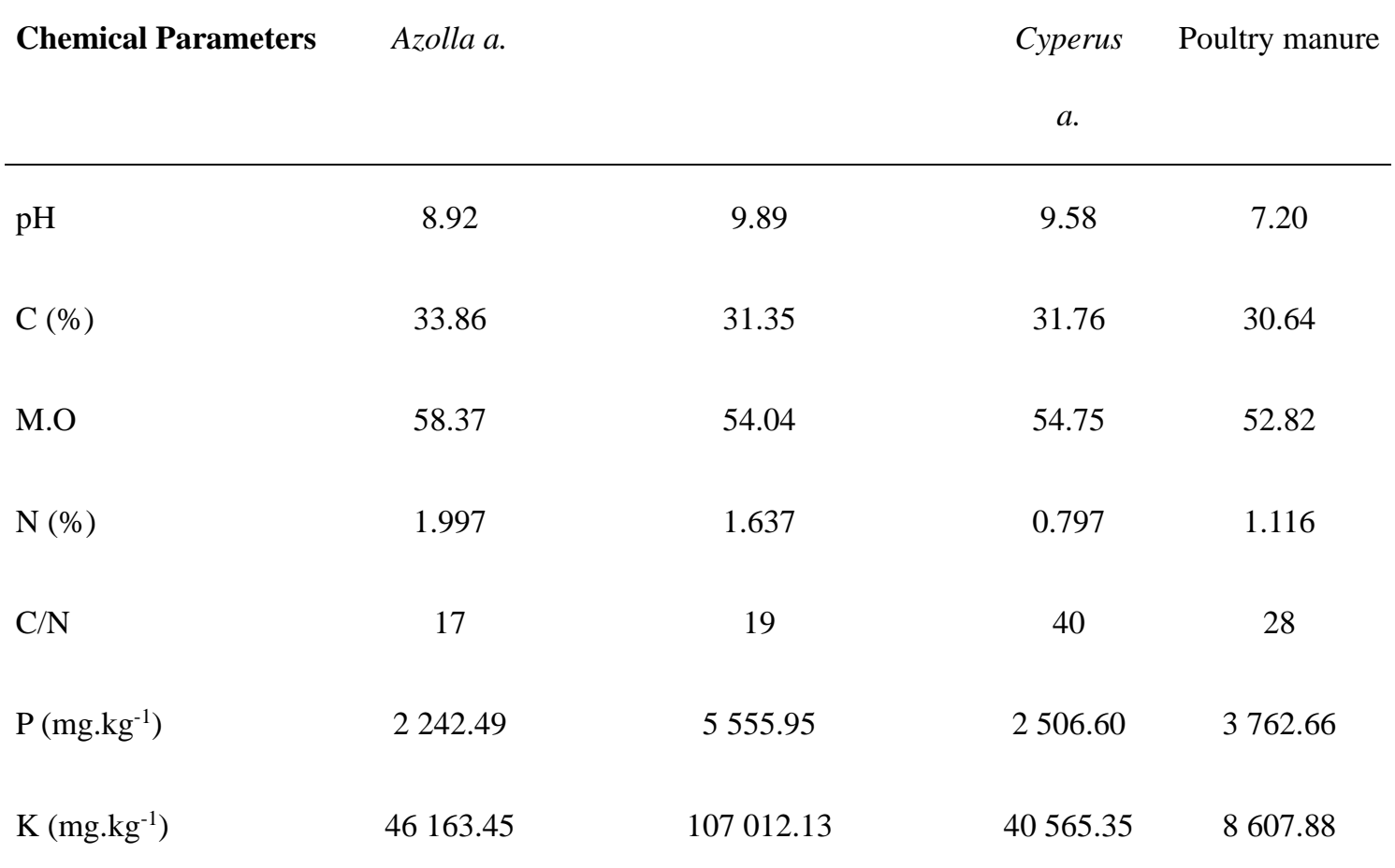

\subsection{Morphological Parameters of Maize Plants as Influenced by the Treatments}

Table 2 shows the results of the analyses of the growth parameters, i.e. height and collar diameter of the young maize plants on the $18^{\text {th }}, 30^{\text {th }}, 37^{\text {th }}$ DAS, and the number of leaves at the $37^{\text {th }}$ DAS. For these two parameters, the analysis of variance revealed non-significant differences at 5\% threshold between treatments. In terms of crown diameter, plots with biochar derived from Myriophyllum a. (T2) has the plants with the highest diameters (on average $1.16 \pm 0.18 \mathrm{~cm}$ ). The plants on plots treated with a combination of biochar obtained from Myriophyllum a. and poultry manure (T6) were relatively smaller in terms of height and stem diameter with average values of $46.17 \pm 4.04 \mathrm{~cm}$ and $0.89 \pm 0.12 \mathrm{~cm}$, respectively. However, this analysis of variance at the $5 \%$ threshold shows significant differences between treatments for the number of leaves on day 37. 
Table 2. Growth parameters (mean $\pm \mathrm{SD}$ ) at various times after sowing

\begin{tabular}{|c|c|c|c|c|c|c|c|}
\hline Treatment & $\begin{array}{l}\text { Height } \\
\text { at } 18^{\text {th }} \\
\text { DAS } \\
(\mathrm{cm})\end{array}$ & $\begin{array}{l}\text { Diameter } \\
\text { of collar } \\
\text { at } 18^{\text {th }} \\
\text { DAS }(\mathrm{cm})\end{array}$ & $\begin{array}{l}\text { Height } \\
\text { at } 30^{\text {th }} \\
\text { DAS } \\
(\mathrm{cm})\end{array}$ & $\begin{array}{l}\text { Diameter } \\
\text { of collar } \\
\text { at } 30^{\text {th }} \\
\text { DAS }(\mathrm{cm})\end{array}$ & $\begin{array}{l}\text { Height } \\
\text { at } 37^{\text {th }} \\
\text { DAS } \\
(\mathrm{cm})\end{array}$ & $\begin{array}{c}\text { Diameter } \\
\text { of collar } \\
\text { at } 37^{\text {th }} \\
\text { DAS } \\
(\mathrm{cm})\end{array}$ & $\begin{array}{c}\text { Number } \\
\text { of } \\
\text { leaves } \\
\text { at } 37^{\text {th }} \\
\text { DAS }\end{array}$ \\
\hline T0 & $\begin{array}{c}27.10 \pm \\
2.56\end{array}$ & $\begin{array}{c}0.35 \pm \\
0.03\end{array}$ & $\begin{array}{c}55.13 \pm \\
5.18\end{array}$ & $\begin{array}{c}1.07 \pm \\
0.15\end{array}$ & $\begin{array}{c}68.83 \pm \\
7.91\end{array}$ & $\begin{array}{c}1.49 \pm \\
0.25\end{array}$ & $\begin{array}{c}10.06^{\mathrm{a}} \pm \\
0.12\end{array}$ \\
\hline $\mathrm{T} 1$ & $\begin{array}{c}24.78 \pm \\
3.46\end{array}$ & $\begin{array}{c}0.34 \pm \\
0.09\end{array}$ & $\begin{array}{c}51.80 \pm \\
5.48\end{array}$ & $\begin{array}{l}1.03 \pm \\
0 ; 19\end{array}$ & $\begin{array}{c}73.22 \pm \\
7.05\end{array}$ & $\begin{array}{c}1.68 \pm \\
0.21\end{array}$ & $\begin{array}{c}10.56^{\mathrm{a}} \pm \\
0.80\end{array}$ \\
\hline $\mathrm{T} 2$ & $\begin{array}{c}27.27 \pm \\
1.80\end{array}$ & $\begin{array}{c}0.36 \pm \\
0.05\end{array}$ & $\begin{array}{c}54.47 \pm \\
5.27\end{array}$ & $\begin{array}{l}1.16 \pm \\
0 ; 18\end{array}$ & $\begin{array}{c}70.78 \pm \\
7.85\end{array}$ & $\begin{array}{c}1.61 \pm \\
0.20\end{array}$ & $\begin{array}{c}10.81^{\mathrm{a}} \pm \\
0.31\end{array}$ \\
\hline $\mathrm{T} 3$ & $\begin{array}{c}28.46 \pm \\
3.24\end{array}$ & $\begin{array}{c}0.40 \pm \\
0.07\end{array}$ & $\begin{array}{c}54.73 \pm \\
6.05\end{array}$ & $\begin{array}{c}1.13 \pm \\
0.22\end{array}$ & $\begin{array}{c}64.75 \pm \\
6.60\end{array}$ & $\begin{array}{c}1.38 \pm \\
0.10\end{array}$ & $\begin{array}{c}9.5^{\mathrm{b}} \pm \\
0.67\end{array}$ \\
\hline $\mathrm{T} 4$ & $\begin{array}{c}25.35 \pm \\
1.49\end{array}$ & $\begin{array}{c}0.32 \pm \\
0.06\end{array}$ & $\begin{array}{c}48.00 \pm \\
4.91\end{array}$ & $\begin{array}{c}0.93 \pm \\
0.11\end{array}$ & $\begin{array}{c}70.51 \pm \\
7.84\end{array}$ & $\begin{array}{c}1.61 \pm \\
0.07\end{array}$ & $\begin{array}{c}10.62^{\mathrm{a}} \pm \\
0.85\end{array}$ \\
\hline $\mathrm{T} 5$ & $\begin{array}{c}24.25 \pm \\
0.93\end{array}$ & $\begin{array}{c}0.31 \pm \\
0.03\end{array}$ & $\begin{array}{c}48.00 \pm \\
3.67\end{array}$ & $\begin{array}{c}0.95 \pm \\
0.08\end{array}$ & $\begin{array}{c}64.98 \pm \\
7.28\end{array}$ & $\begin{array}{c}1.40 \pm \\
0.16\end{array}$ & $\begin{array}{c}9.75^{\mathrm{b}} \pm \\
0.73\end{array}$ \\
\hline T6 & $\begin{array}{c}23.58 \pm \\
2.75\end{array}$ & $\begin{array}{c}0.29 \pm \\
0.04\end{array}$ & $\begin{array}{c}46.17 \pm \\
4.04\end{array}$ & $\begin{array}{c}0.89 \pm \\
0.12\end{array}$ & $\begin{array}{c}61.06 \pm \\
5.37\end{array}$ & $\begin{array}{c}1.33 \pm \\
0.12\end{array}$ & $\begin{array}{c}9.56^{\mathrm{b}} \pm \\
0.31\end{array}$ \\
\hline $\mathrm{T} 7$ & $\begin{array}{c}26.07 \pm \\
3.27\end{array}$ & $\begin{array}{c}0.34 \pm \\
0.05\end{array}$ & $\begin{array}{c}48.79 \pm \\
7.51\end{array}$ & $\begin{array}{c}0.96 \pm \\
0.17\end{array}$ & $\begin{array}{c}63.43 \pm \\
8.87\end{array}$ & $\begin{array}{c}1.35 \pm \\
0.23\end{array}$ & $\begin{array}{c}9.68^{\mathrm{b}} \pm \\
0.77\end{array}$ \\
\hline $\mathrm{T} 8$ & $\begin{array}{c}26.85 \pm \\
1.22\end{array}$ & $\begin{array}{c}0.34 \pm \\
0.04\end{array}$ & $\begin{array}{c}52.10 \pm \\
6.28\end{array}$ & $\begin{array}{c}1.05 \pm \\
0.14\end{array}$ & $\begin{array}{c}69.08 \pm \\
9.51\end{array}$ & $\begin{array}{c}1.55 \pm \\
0.22\end{array}$ & $\begin{array}{c}10.43^{\mathrm{a}} \pm \\
0.3\end{array}$ \\
\hline $\mathrm{T} 9$ & $\begin{array}{c}26.11 \pm \\
2.68\end{array}$ & $\begin{array}{c}0.33 \pm \\
0.05\end{array}$ & $\begin{array}{c}51.15 \pm \\
7.74\end{array}$ & $\begin{array}{c}0.98 \pm \\
0.18\end{array}$ & $\begin{array}{c}68.28 \pm \\
9.76\end{array}$ & $\begin{array}{c}1.49 \pm \\
0.24\end{array}$ & $\begin{array}{c}10.31^{\mathrm{a}} \pm \\
0.85\end{array}$ \\
\hline $\operatorname{Pr}>F$ & 0.211 & 0.532 & 0.319 & 0.379 & 0.523 & 0.170 & 0.041 \\
\hline Significance & NS & NS & NS & NS & NS & NS & $\mathrm{S}$ \\
\hline
\end{tabular}

Values in the same column affected by the same letter are not statistically different at the 5\% probability threshold (ANOVA, Tukey-Dunnett Test). T0: control with neither biochar nor poultry manure, T1: biochar obtained from Azolla a., T2: biochar obtained from Myriophyllum a., T3: biochar obtained from Cyperus a., T4: combination of biochar obtained from Azolla a., Myriophyllum a. and Cyperus a., T5 : association biochar from Azzola + poultry manure, T6: association biochar from Myriophyllum + poultry manure, T7: association biochar from Cyperus + poultry manure, T8: mineral fertilizer, T9: association of poultry manure + mixture of biochar from Azolla a., Myriophyllum a. and Cyperus a. $\operatorname{Pr}>\mathrm{F}$ : observed probability, NS: not significant, S: Significant. 


\section{Macrothink}

\subsection{Typology of the different treatments}

The second axis (F2) explains $14.49 \%$ of the information contained in the growth parameter measurements. The variable number of leaves on day 37 after sowing is positively correlated to this axis. Axis 2 mainly opposes plants with faster growth to those with relatively slower growth. It can be interpreted as the axis representing the result of the growth of the plants from the different treatments. The two axes alone explain $94.88 \%$ of the total information.

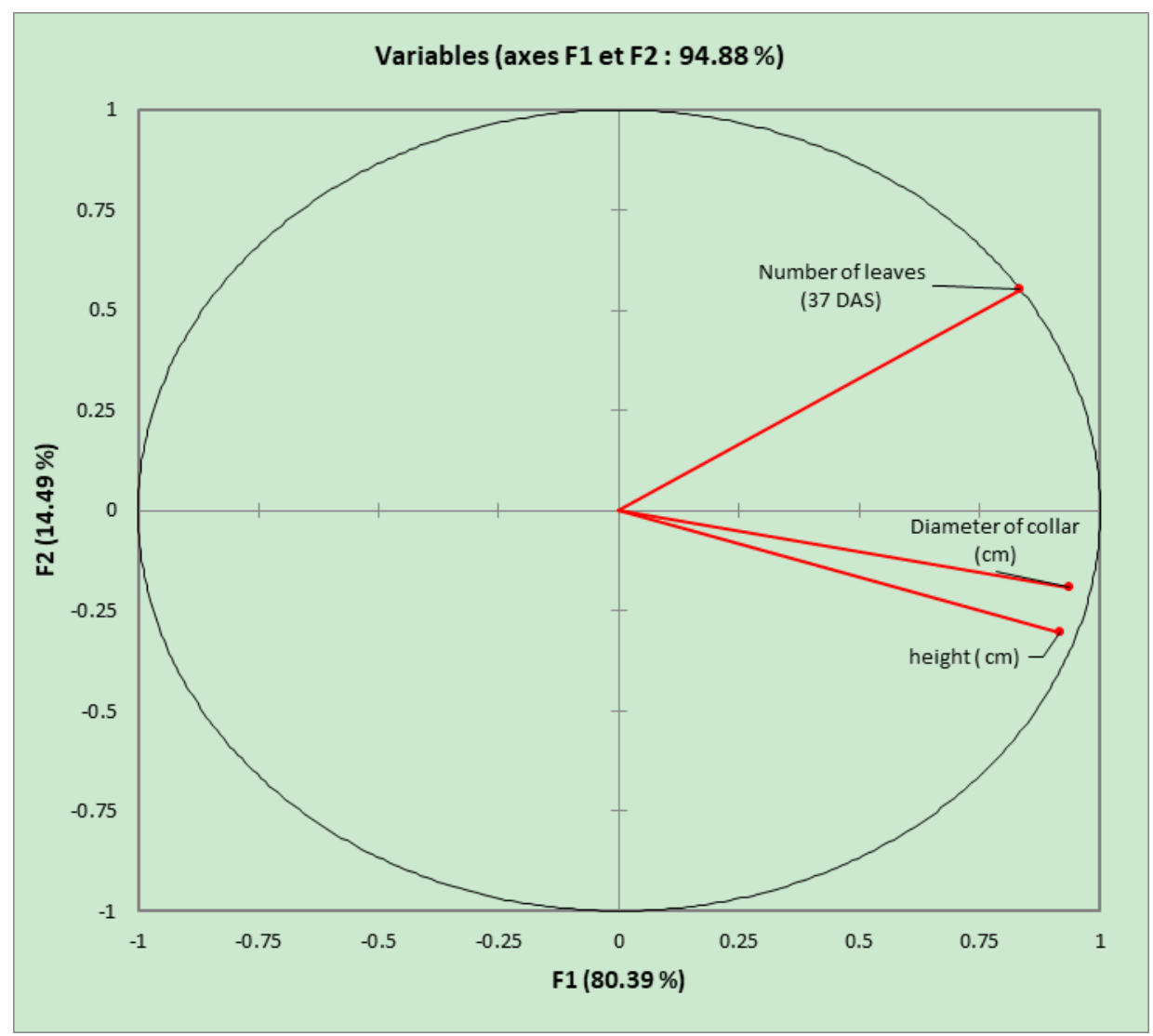

Figure 1. Graphical representation of variables on axes 1 and 2 from Principal Component Analysis (PCA)

These two axes make it possible to capture most of the information. The table 3 shows the linear correlation between the variables and axes F1 and F2.

Table 3. Linear correlation between variables and axes 1 and 2

Variables

Height $(\mathrm{cm})$

Diameter at collar $(\mathrm{cm})$

Number of leaves (37 DAS)
Axe F1

Axe F2

0.916

$-0.305$

0.937

$-0.192$

0.833

0.552 
Figure 2 shows the distribution of treatments into different classes derived from the Hierarchical Ascending Classification (HAC) based on the variables used in the PCA. Three classes of treatments are distinguished. Each of these classes comprises between $30 \%$ (classes 1 and 2) and $40 \%$ (class 3) of the 10 treatments. Table 4 summarizes the characteristics of these different classes.

\section{Class 1}

This class accounts for $30 \%$ of treatments and is the second largest class in terms of staff numbers. It mainly includes treatments where the average height of the plants is $68.73 \pm 0.40$ $\mathrm{cm}$. The collar diameters of the plants resulting from these treatments have an average value of $1.51 \pm 0.03 \mathrm{~cm}$. The average number of leaves of the plants resulting from these treatments is $10.27 \pm 0.19$. It includes treatments comprising either no input, mineral fertilizer $(180 \mathrm{~g})$ or a combination of biochar and poultry manure (1 kg biochar of Azolla a.+1 kg biochar of Myriophyllum a.+ $1 \mathrm{~kg}$ biochar of Cyperus a.+ $3 \mathrm{~kg}$ poultry manure). These treatments correspond respectively to $\mathrm{T} 0, \mathrm{~T} 8$ and $\mathrm{T} 9$.

\section{Class 2}

This category also includes $30 \%$ of the treatments and similar to class 1, represents the second class in terms of number of plants and presents the plants with the best morphological parameters. In fact, it mainly includes treatments where the plants have an average height of $71.50 \pm 1.49 \mathrm{~cm}$. The average diameter at the collar of the plants resulting from these treatments is $1.63 \pm 0.04 \mathrm{~cm}$. The mean number of leaves of the plants resulting from these treatments is $10.66 \pm 0.13$. This class includes almost all the biochar treatments except for the treatment with Cyperus a.biochar (T3). This class is therefore made up of treatments with either Azolla a.biochar (6 kg), Myriophyllum a.biochar (6 kg), or a mixture of Azolla a.biochar (2 kg), Myriophyllum a.biochar (2 kg) and Cyperus a.biochar $(2 \mathrm{~kg})$. These treatments correspond respectively to T1, T2, and T4. So, biochar of Azolla a. and of Myriophyllum a.had a positive effect on plant growth parameter (included the combination of the two).

\section{Class 3}

This class accounts for $40 \%$ of treatments and is the largest class in terms of staff numbers. It mainly includes treatments where the average height of the plants is $63.55 \pm 1.79 \mathrm{~cm}$. The average collar diameter of the plants resulting from these treatments is $1.37 \pm 0.03 \mathrm{~cm}$. The average number of leaves of the plants resulting from these treatments is $9.62 \pm 0.11$.

It includes treatments obtained either from the mixture of biochar $(3 \mathrm{~kg})$ and poultry manure (3 kg) or from biochar of Cyperus a. $(6 \mathrm{~kg})$. These treatments correspond respectively to T5, T6, T7 and T3 and had negative effect (no effect of biochar of Cyperus $a$., addition of poultry manure had no effect and more over seems to have negative effect). 


\section{Macrothink}

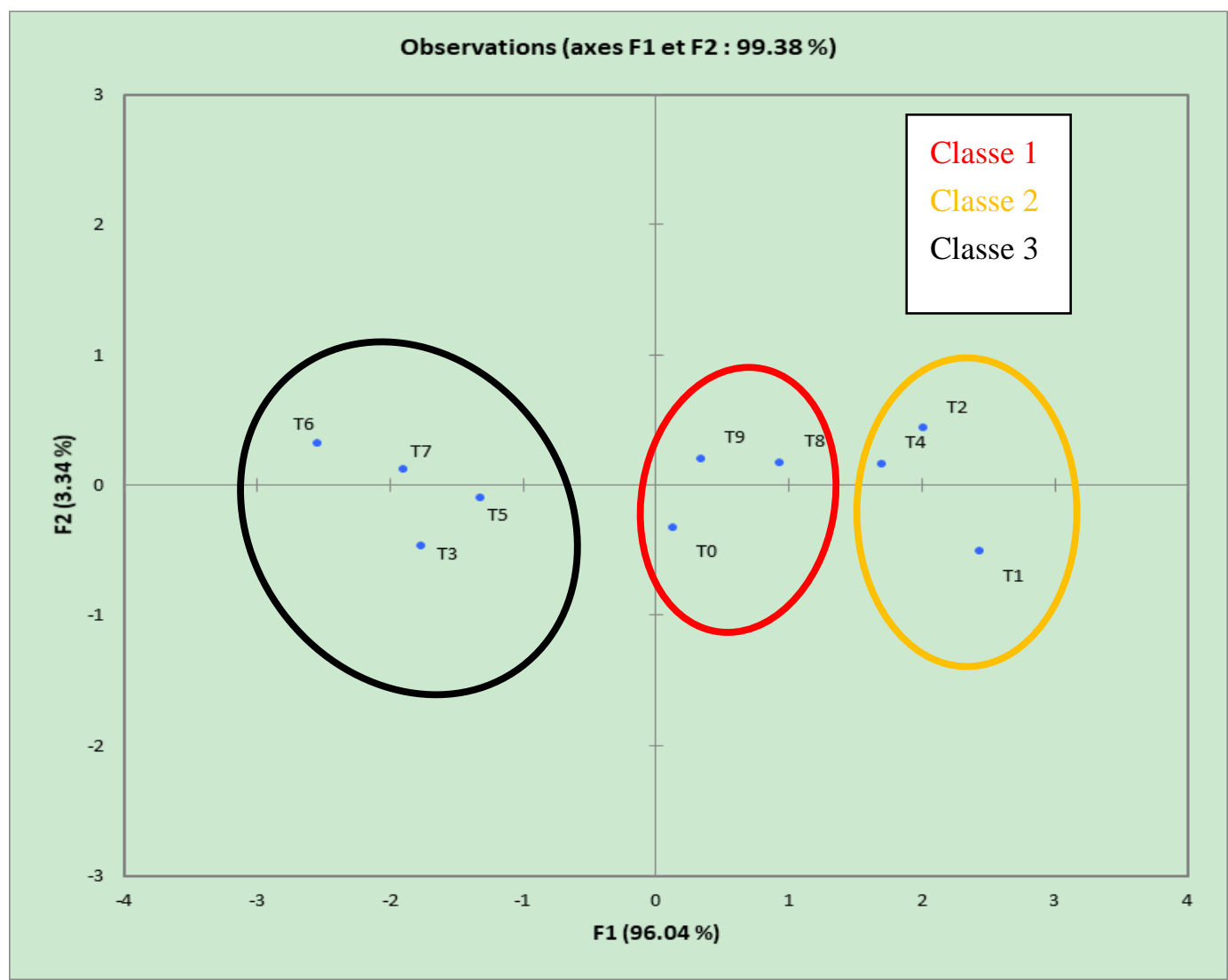

Figure 2. Graphical representation of the processing of the individual evaluation classes from the hierarchical bottom-up classification (HPC)

Table 4. Characteristics of the three categories resulting from the hierarchical ascending classification

\begin{tabular}{lccc}
\hline Variables & Class 1 $(\mathrm{n}=3)$ & Class 2 $(\mathrm{n}=3)$ & Class 3 $(\mathrm{n}=4)$ \\
\hline Height (37th DAS*) & $68.73 \pm 0.40$ & $71.50 \pm 1.49$ & $63.55 \pm 1.79$ \\
Diameter (37th DAS) & $1.51 \pm 0.03$ & $1.63 \pm 0.04$ & $1.37 \pm 0.03$ \\
Number of leaves (37th DAS) & $10.27 \pm 0.19$ & $10.66 \pm 0.13$ & $9.62 \pm 0.11$ \\
Percentage of sample & $30 \%$ & $30 \%$ & $40 \%$ \\
\hline
\end{tabular}

*DAS: Days after sowing

\section{Discussion}

The chemical composition of the three biochar-types are consistent with those of Unger et al., (2011) and Ding et al. (2016) who showed that the composition and availability of mineral elements in biochar differ depending on feedstock and pyrolysis conditions. According to Lange et al. (2018), the $\mathrm{N}$ concentration tend to be lower in biochar and are usually less than $6 \%$. These results are supported by the findings in this study. Indeed, the $\mathrm{N}$ concentration was $1.997 \%$ for Azolla a.derived-biochar, $1.637 \%$ for the Myriophyllum a.-biochar and $0.797 \%$ for that of Cyperus a.-biochar.

Phosphorus plays a role in a range of plant metabolic functions and is one of the essential nutrients needed for plant growth and development. Phosphorus $(\mathrm{P})$ is absorbed primarily 
during vegetative growth and, subsequently, most of the absorbed phosphorus is transferred to fruits and seeds during the reproductive stages (Zapata et al., 1994). According to Chan and $\mathrm{Xu}$ (2009), the contents of phosphorus in biochars vary according to the biomass type and pyrolysis conditions. The exceptional level of phosphorus contained in the biochar obtained from Myriophyllym a., (5 $555.95 \mathrm{mg} / \mathrm{kg}$ ) indicate that this biochar probably greatly increased the soil phosphorus content and will contribute to make it available to maize plants. Potassium (K) allows the flowering and development of the fruit and all reserve organs such as roots and tubers. Thanks to the potassium, the colouring of flowers and fruits is improved as well as the resistance to diseases. Considering the low potassium content of the soil before amendment $(104.83 \mathrm{mg} / \mathrm{kg})$, the high potassium contents of the different amendments (107 $012.13 \mathrm{mg} / \mathrm{kg}$ for the biochar of Myriophyllum a., $46163.45 \mathrm{mg} / \mathrm{kg}$ for the biochar of Azolla a., $40565.35 \mathrm{mg} / \mathrm{kg}$ for Cyperus a.and finally $8607.88 \mathrm{mg} / \mathrm{kg}$ for poultry droppings) probably contributed to the availability of potassium to the plants.

The proportion of minerals from the various combinations could justify why there was no added influence of the combination of biochar (the same outcome with one or with the inclusion of three).

Several studies have shown that poultry manure raises levels of organic matter, cation exchange capacity, the number of microorganisms and their activities in soils (Guidi et al., 1988; MacLaren and Cameron, 1996). The addition of poultry droppings with other fertilizers would significantly influence all maize yield parameters. According to Gomgnimbou et al. (2016), poultry droppings are an excellent organic fertilizer for crops and could have the same impact as the mineral NPK fertilizer. Indeed, the nitrogen contained in poultry droppings is rapidly available to the plant. It is the same for the other fertilizing elements they contain. They are to be used as a fertilizer rich in nitrogen, phosphorus, potassium and calcium with a basic amending effect on the soil (Gazeau et al., 2012). The addition of poultry manure to biochars had no effect and seems to have negative effect on the growth of plants. The combination of the biochar of invasive aquatic plants that is rich with the already rich poultry droppings has resulted in the "burning" of plant roots.

The results of the analysis of the $\mathrm{pH}$ of biochar obtained from the studied invasive aquatic plants (8.92 for Azolla a.biochar, 9.58 for Cyperus a.biochar and 9.89 for Myriophyllum a.) show that they are likely to raise the $\mathrm{pH}$ of acidic soils. These results corroborate those of Chintala et al., 2014 and Kombatanga (2015) who found that biochar increase soil pH. The results of the trials show that only biochars produced from Azolla a.and of Myriophyllum a.had a positive effect on plant growth (including the combination of both) and no effect of biochar of Cyperus a.. This is due to the fact that these two species (Azolla a.and of Myriophyllum a.) incorporate nitrogen and phosphorus. Indeed, Azolla a.has a symbiotic association with cyanobacteria. Symbiosis allows the fern to develop better by taking advantage of the ability of cyanobacteria to absorb atmospheric nitrogen. In addition, one of the growing conditions of Azolla a.is the supply of phosphorus and, to a lesser extent, calcium, magnesium and trace elements. Azolla a.is used as a biofertilizer in rice fields because of its ability to fix nitrogen in the soil and block light to prevent competition from other plants, and is rich in protein, essential amino acids, vitamins and minerals (Gillard 2017). 
Myriophyllum a.is a perennial aquatic plant capable of growing both below and above the water surface and thrives in stagnant or low-flow nitrogen-enriched waters. Like Azolla a., the growth of Myriophyllum a.is promoted by nutrient inputs (nitrogen, phosphates, potassium) from fertilizer discharges and urban or industrial wastewater (Hussner and Champion, 2011). Unlike Azolla a. and Myriophyllum a., Cyperus a.is an aphyl plant, without leaves. It is a semi-aquatic species that colonizes the average depths of bodies of water and streams, on clay soils. Its capacity to incorporate nutrients (nitrogen, phosphates, potassium) is low compared to Azolla a.and Myriophyllum a.

\section{Conclusion}

The results of the trials show that the biochars obtained from Azolla a.and Myriophyllum a.had a positive effect on maize plant growth. This can be explained by the compositions and the properties of the species.

During this study, we found that poultry droppings, which are high-nitrogen fertilizers, in combination with biochar obtained from invasive aquatic plants, has a potential of influencing plant growth. However, the appropriate amount to apply need to be determined to avoid negative effects.

Our findings suggest that the biochar from IAP such us Azolla a.and Myriophyllum a., have higher potentials to improve plant growth parameters than either the poultry manure or mineral fertilizer.

Based on our findings, we suggest that the use of IAP biochar be encouraged among smallholder farmers (particularly those with farmlands close to wetlands), as it is environmentally sustainable, easy to produce, has a lower operating cost than other fertilizers, and with proven ability to improve the acidic and impoverished soils prevalent in Burkina Faso, a Sahelian country.

\section{Acknowledgements}

This research was conducted as part of the West Africa Biodiversity and Ecosystem Services (WABES) project (No.: 16_IV_072_A), sponsored by the International Climate Initiative (IKI) of the German Federal Ministry for the Environment, Nature Conservation, and Nuclear Safety (BMU), Germany.

\section{References}

Adekiya, A. O., Agbede, T. M., Olayanju, A., Ejue, W. S., Adekanye, T. A., Adenusi, T. T., Ayeni, J. F. (2020). Effect of Biochar on Soil Properties, Soil Loss, and Cocoyam Yield on a Tropical Sandy Loam Alfisol, The Scientific World Journal, 2020, Article ID 9391630, 9 pages, 2020. https://doi.org/10.1155/2020/9391630

Almoustapha, O., \& Millogo-Rasolodimby, J. (2006). Production de biogaz et de compost à partir de eichhornia crassipes, (mart) solms-laub (pontederiaceae) pour un développement durable en Afrique sahélienne. VertigO: la revue électronique en science de l'environnement. Open Edition Journal, 7, 47p. https://doi.org/10.4000/vertigo.2221 
Belem, M. (2008). Impacts de la gestion de la Reserve de Biosphère de la mare aux hippopotames sur les activités socio-économiques des populations riveraines, Burkina Faso. $15^{\text {ième }}$ Colloque international en Evaluation Environnementale sur: « Evaluation environnementale et biodiversité », 20-23 Septembre 2010, Paris, France, pp 200-220.

Chan, K. Y., \& Xu, Z. (2009). Biochar: nutrient properties and their enhancement. In: Lehmann, J., Stephen, J. (Eds): Biochar for environmental management. Science and technology. Earthscan Washington. pp: 67-84.

Chintala, R., Mollinedo, J., Schumacher, T. E., Malo, D. D., \& Julson, J. L. (2014). Effect of biochar on chemical properties of acidic soil. Arch Agron Soil Sci., 60, 393-404. https://doi.org/10.1080/03650340.2013.789870

Ding, Y., Liu, Y., Liu, S., Li, Z., Tan, X., Huang, X., Zeng, G., Zhou, L., \& Zheng, B. (2016). Biochar to improve soil fertility. Agronomy for Sustainable Development, 40, 12-36. https://doi.org/10.1007/s13593-016-0372-z

Egnankou, A. P. (2016). Les choix de pratiques agricoles à partir du cas des paysans agni de Bettié, adioukrou d'Orbaff et ébrié de Songon-Agban (Côte d'Ivoire), Cahiers de sociologie économique et culturelle, 61, 11-34

Gazeau, G., Bouvard, F., \& Leclerc, B. (2012). Fientes de volaille. (Matière Organique Fiche $\left.\mathrm{N}^{\circ} 19\right)$ 2P. Maison des Agriculteurs -22 rue Henri Pontier 13626 Aix-en-Provence Cedex (France)

Gillard, M. (2017). Réponses de plantes aquatiques invasives au réchauffement climatique. Thèse de Doctorat de l'université Rennes 1, France, 217p.

Gomgnimbou, A. P. K., Coulibaly, K., Sanon, A., Bacyé, B. B., Nacro, B. H., Sedogo, P. M. (2016). Study of the Nutrient Composition of Organic Fertilizers in the Zone of Bobo-Dioulasso (Burkina Faso). IJSRSET, 4(2), 617-622.

Guidi, G., Pera, A., Giovanetti, M., Poggio, G., \& Beryoldi, M. (1988). Variations of soil structure and microbial population in a compost amended soil. Plant Soil, 106, 113-119. https://doi.org/10.1007/BF02371202

Hussner, A., \& Champion, P. D. (2011). Myriophyllum aquaticum (Vell.) Verdcourt (parrot feather). In: Francis R.A (ed) Handbook of Global Freshwater Invasive Species, Rout-ledge, New York (USA), 423-456.

Hussner, A., Stiers, I., Verhofstad, M. J. J. M., Bakker, E. S., Grutters, B. M. C., Haury, J., ... Hofstra, D. (2017). Management and control methods of invasive alien freshwater aquatic plants: a review. Aquatic Botany, 136, 112-137. https://doi.org/10.1016/j.aquabot.2016.08.002

IPBES, (2018). Scoping for a thematic assessment of invasive alien species and their control. Plenary of the Intergovernmental Science-Policy Platform on Biodiversity and Ecosystem Services, Sixth session, 18-24 March 2018, Medellin, Colombia, pp 2-6.

Kombamtanga, A. (2015). Effets du biocharbon et des modes de gestion de l'eau sur les 
propriétés physico-chimiques du sol et les rendements du chorchorusolitorius en agriculture urbaine: Cas du site maraîcher de Wayalghin. Mémoire de fin de cycle ISEDR, Université de Dédougou Burkina Faso, 108p.

Lange, S. F., Allaire, S. E., Charles, A., Auclair, I., \& Bajzak, C. E. (2018). Proprietes physicochimiques de 43 biochars. Rapport technique CRMR-2018-SA1. Centre de Recherche sur les Materiaux Renouvelables, Universite Laval et GECA Environnement, Quebec, Canada, $60 \mathrm{p}$.

Lee, S. S., Shah, H. S., Awad, Y. M., Kumar, S., \& Ok, Y. S. (2015) Synergy effects of biochar and polyacrylamide on plants growth and soil erosion control. Environmental Earth Sciences, 74(3), 2463-2473. https://doi.org/10.1007/s12665-015-4262-5

Lehmann, J., \& Joseph, S. (2009). Biochar for environmental management: science and technology. First edition, Earthscan, London (UK), 1, 405p.

Lompo, D. J. P., Yé, L., Balboné, A., \& Sori, S. I. (2021a). Effets combinés du biocharbon et $\mathrm{du}$ fumier sur les propriétés physico-chimiques d'un sol ferrugineux tropical sous culture de mil en zone semi-aride du Burkina Faso. Journal of Applied Biosciences, 157, 16172-16181. https://doi.org/10.35759/JABs.157.3

Lompo, D. J. P., Yé, L., Ouédraogo S., Sori, S. I., \& Nacro, H. B. (2021b). Production and Characterization of Crop Residues Derived Biochars for Soil Amendment and Carbon Sequestration. Journal of Agricultural Studies, 9(1). https://doi.org/10.5296/jas.v9i1.17890

MAAH, (2016). Rapport bilan de la campagne agricole de saison sèche 2015-2016, Ministère de l'Agriculture et des aménagements Hydraulique. Rapport Bilan, Ouagadougou, Burkina Faso, 18p.

Mack, R. N., Simberloff, D., Lonsdale, W. M., Evans, H., Clout, M., \& Bazzaz, F. A. (2000). Biotic invasions: causes, epidemiology, global consequences, and control. First edition, Issue in Ecology, Washington (USA), 22 . https://doi.org/10.1890/1051-0761(2000)010[0689:BICEGC]2.0.CO;2

McLaren, R. G., \& Cameron, K. C. (1996). Sustainable production and environmental protection. 2nd Edition, Soil science, Oxford University Press, Auckland, New Zealand.

Mukherjee, A., \& Lal, R. (2013) 'Biochar Impacts on Soil Physical Properties and Greenhouse Gas Emissions', Agronomy, 313-339. https://doi.org/10.3390/agronomy3020313

ORSTOM, (1968). Etude Pédologique de la Haute volta. Science de la terre. 99p.

Ouedraogo, R. L. (1994). Etude de la végétation aquatique et semi-aquatique de la mare aux hippopotames de Bala et des mares d'Oursi et de Yomboli. Thèse de Doctorat de troisième cycle, FAST, Université de Ouagadougou, Burkina Faso, 191p.

PNGIRE, (2016). Ministère de l'Eau et de l'Assainissement (MEA) du Burkina Faso. Rapport PN-GIRE - 2016-2030, Ouagadougou, Burkina Faso, 76p. 
Strayer, D. L. (2010). Alien species in fresh waters: ecological effects, interactions with other stressors, and prospects for the future. Freshwater biology, 55, 152-174. https://doi.org/10.1111/j.1365-2427.2009.02380.x

Taita, P. (1998). Etude quantitative de la vegetation de l'aire centrale de la réserve de Biosphère la mare aux hippopotames. SC., 23(2), 121-135.

Unger, R., Killorn, R., \& Brewer, C. (2011). Effects of Soil Application of Different Biochars on Selected Soil Chemical Properties. Commun Soil Sci Plant Anal., 42, 2310-2321. https://doi.org/10.1080/00103624.2011.605489

Verheijen, F., Jeffery, S., Bastos, A. C., Van der Velde, M., \& Diafas, I., (2010). Biochar application to soils. A critical scientific review of effects on soil properties, processes, and functions. EUR, 24099, 162.

Walinga, I., Van Vark, W., Houba, V. J. G., Van Der Lee, J. J. (1989). Plant analysis procedures. Dpt. Soil Sc. Plant Nutr. Wageningen Agricultural UniversitySyllabus, Part, 7, 197-200.

Walkley, A., \& Black, I. A. (1934). An examination of Degtjareff method for determining soil organic matter and a proposed modification of the chromic acid titration method. Soil Science, 37, 29-37. https://doi.org/10.1097/00010694-193401000-00003

Woolf, D., Amonette, J. E., Street-Perrott, F. A., Lehmann, J., \& Joseph, S. (2010). Sustainable biochar to mitigate global climate change. Nature communications, 1(1), 1-9. https://doi.org/10.1038/ncomms 1053

Yao, Y., Gao, B., Zhang, M., Inyang, M., \& Zimmerman, A. R. (2012). Effect of biochar amendment on sorption and leaching of nitrate, ammonium, and phosphate in a sandy soil. Chemosphere, 89, 1467-1471. https://doi.org/10.1016/j.chemosphere.2012.06.002

Zapata, F., Casanova, E., Salas, A. M., \& Pino, I. (1994). Dynamics of phosphorus in soils and phosphate fertilizer management in different cropping systems through the use of isotopic techniques. 15th edition of World Congress Soil Sci., ISSS \& MSSS, Commission IV Symposia, Acapulco, Mexico 5a, 466p.

\section{Copyright Disclaimer}

Copyright for this article is retained by the author(s), with first publication rights granted to the journal.

This is an open-access article distributed under the terms and conditions of the Creative Commons Attribution license (http://creativecommons.org/licenses/by/4.0/). 